Gorana Đorić

Faculty of Philosophy

Niš
UDK: 316.344 .8

Оригиналан научни рад

Примљен: 5. 03. 2007.

\title{
MAKING WELFARE REGIME ANALYSIS SENSITIVE TO GENDER RELATIONS ${ }^{1}$
}

This paper is a discussion of the most representative contributions to the study of gender and welfare states from the comparative perspective. In the first section of the paper we follow the development of the gender and welfare state analyses that brought these two separate theoretical and empirical interests together; in the second section we follow the internal development of the comparative welfare regime analysis with respect to gender relations, which was brought about by this convergence. Building on these contributions, we describe our own framework for the analysis of the implications of the socio-economic transformation in post-socialist countries on gender inequality in economic wellbeing. We introduce a three dimensional classification of women on which rather abstractly defined gender content of welfare regimes could be actually empirically measured. policy.

Key words: welfare regime, gender inequality, caring regimes, family gap, family

In this paper an overview is presented of the achievements in the comparative welfare regime analysis with respect to gender relations. According to this analysis different welfare regimes have different stratification effects and, in particular, different effects on gender inequality. We consider this scholarship a useful theoretical background to be familiar with when addressing the impact of institutional transformation in post-socialist countries ${ }^{2}$ on the gender inequality in economic wellbeing. In the first section of the paper we follow the development of the gender and welfare state analyses that brought these two separate theoretical and empirical interests together; in the second section we follow the internal development of the comparative welfare regime analysis with respect to gender relations, which was brought about by this convergence. The presentation of these developments is inevitably very schematic, and focused on the selected reference points that have led to the theoretical framework chosen for our own research. In the third section, we

\footnotetext{
${ }^{1}$ The paper is a slightly modified chapter from the authors DPhil thesis on "The Effects of Socio-economic Transformation on Gender Inequality in Economic Wellbeing: the Hungarian Experience from 1992 to 1999" submitted at the University of Oxford, 2007.

${ }^{2}$ Which we assume to add up to a welfare regime change, in which case the two regimes with differential implications for gender inequality being a socialist centrally planned economy and a market regulated economy which has been introduced.
} 
sketch our own framework for the analysis of the implications of the socio-economic transformation in post-socialist countries on gender inequality.

\section{A 'pre-history' of comparative view of gender and welfare states}

One of the main arguments of gender analyses is that social resources of different kinds are distributed unequally between men and women, due to the sexual division of labour. In the context of gender analysis, the sexual division of labour is not recognised as having a natural basis, but is assigned to the social construction of proper male and female social roles. The tasks that were in the focus of gender informed research included a demonstration of social inequalities between men and women, an analysis of the mechanisms of the social construction of the two genders (as opposed to the two biological sexes) and a critique of the 'gender blind' theoretical accounts of the social world.

In relation to social policy and the welfare state, gender informed research has focused on the different basis of women's entitlements to social benefits that, given the two tiered system of social provision (social insurance/social assistance) has constructed women as recipients of a 'second rate' (social assistance) social provision. Related to women's access to contributory social provision schemes is the interest in different patterns of labour force participation of men and women. Further related to this set of issues are the issues of child care provision (as it helps female labour force participation) and evaluation of caring work and unpaid work in general. Another focus of the 'feminization of poverty' can be identified: the phenomenon of the disproportionate female share in the lowest standard social groups (senior citizens and single headed households). Several underlining assumeptions of the above type of research can be highlighted:

- There is a sexual division of labour: men provide income through employment while women are in charge of household tasks (including child and old age family members care).

- Women's labour force participation primary assumes interrupted, part time, low paid work.

- The predominant mechanisms of social resources distribution are market and work related social policy schemes.

- Caring work at home is in no way socially and economically recognised.

These assumptions were accepted by a vast majority of researchers because they accurately described the state of affairs in Anglo-Saxon countries where this kind of research predominantly took place.

At the same time, the 'mainstream' theory and research (the one that does not focus on and mainly ignores gender dimension of social structure) dealt primarily with the conditions of development of the welfare state, its redistributive capacity and evaluation of the welfare state's success (that is, its redistributive outcomes measured mainly on the bases of the expenditure data). The redistributive capacity 
of the welfare state was assessed based on the extent to which it reduces class (market based) inequality. ${ }^{3}$ Although, the two scholarships differed in relation to what the welfare state represents, they shared the conviction that the welfare state was a unique post-World War II institution and that it was one of a kind.

Of special interest for the development of the analysis of the gender content of welfare states, has been Marshall's theory of social rights based on citizenship (Marshall 1950). Its relevance steams from two points at least. First, it provided the background theory for 'power resource' school and its claims for the parliamentary dissolution of the capitalist society. The argument was that the expansion of social rights based on citizenship, which would come about through the majority vote in the parliament, will eventually 'undo' class inequalities. In other words, by means of social rights, income redistribution, collective services, full employment and education, the welfare state (perceived as an inevitable consequence of legal and political democracy) is capable of undoing class divisions and inequalities created by a capitalist economy. Fertilised by Titmuss' three ideal types of welfare states, Marshall's theory of social rights based on citizenship provided Esping-Anderson (1990) with a dimension (de-commodification) for comparative analysis of welfare states. That welfare states may differ in their emancipatory (or more modestly equalising) capacities was a necessary prerequisite if researchers of gender relations were to look at the institution of the welfare state with a more sympathetic eye and even to consider it a possible ally in a reconstruction of gender relations. In a nutshell, Marshall's work led to the qualitative comparison of different welfare states, and further to the comparison of the gender quality of different welfare states.

The other reason that makes Marshall's theory an important reference point is the concept of citizenship. In Marshall's interpretation, it has a sociological (not only a political) dimension, because it referrers to the conditions in modern societies under which a person obtains the status of a full member of a society. In Parsons' terminology, citizenship was understood as the principle of inclusion in modern societies. It refers to a relation between individual and state that destroys all group privileges before the law, and gives to a citizen - a legitimate member of a society - the opportunity for political participation and well-being as a matter of right. It is in this sense that Marshall's concept of citizenship (social citizenship in particular) has provided many researchers with a reliable point of departure to reflect upon gender and welfare state in anew way: not only class but gender also must be understood as an element in the construction of citizenship. Studies have focused on

"whether and to what extent care, especially in the private sphere, tends to exclude people (women) from social citizenship or whether the responsibilities of care in practice effect a distinctive identity of citizenship" (Bussemaker \& van Kersbergen, 1994:16).

\footnotetext{
${ }^{3}$ For an overview see Pierson (1991).
} 
Could the welfare state undo gender division?

"There appears to be some convergence around the thesis that in nations where the state effectively transfers the private duty to the public responsibility of care, the conditions for the development of a full civil, political and social citizenship of women are better fulfilled" (Bussemaker \& van Kersbergen 1994:16).

An example of such a gender-neutral welfare regime has often been found in Nordic countries, where the provision of public child-care and parental leave has stimulated women's labour market participation. Employment, in its turn, has provided women with a substantial degree of independence in relation to their spouses.

However, as has already been pointed out, the fruitful application of the citizenship concept on the conditions of full social membership for women did not immediately follow Marshall's work, but was mediated by the Esping-Anderson's 'transformation' of the concept into a qualitative dimension of welfare state variation (de-commodification). It, also, had to wait for a positive evaluation of the Nordic model by the Scandinavian feminists (Bussemaker \& van Kersbergen 1994:18). The early reaction of gender focused theory to both the institution and the theory of welfare state was quite negative. The institution of the welfare state was studied as a site of female oppression (from both capitalist and patriarchy based discrimination view points ${ }^{4}$ ) being inherently (ultimately) conditioned upon an asymmetrical sexual division of labour. It was assumed that the welfare state reinforced, if not created gender inequalities. The theory of the welfare state was criticised for not recognising the gender dimension (that is, assumed different social roles for men and women) as constitutive for welfare state institutional arrangements. The concept of citizenship applied in the 'mainstream' analysis of welfare state was criticized for generalising the conditions of social membership of a particular group in a society (male workers) to the conditions for the social participation for all. The argument was that under those conditions women's entitlements to social rights as well as their access to social benefits may be seriously undermined ${ }^{5}$.

The early feminist scholarship on the welfare state was characterised, in our opinion, by two major shortcomings in respect to the analysis of gender based inequalities in a comparative welfare state context. The generic model of the welfare state with which it operated did not provide much of a framework for gender analysis that would allow for welfare state differences. The experience of the Anglo-Saxon countries was interpreted as universally relevant for women/genderwelfare state relations (Wilson 1977; Fraser 1989; Pateman 1988; Skocpol \& Ritter 1991; Gordon 1990). Secondly, the research operated with the non-specific

\footnotetext{
${ }^{4}$ For an overview of this literature see Williams (1989) and Pierson (1991)

${ }^{5}$ This critic was very influential in the circles of gender relations researchers. However, I find this view not quite a fair one: Do women get different share of social resources because they are second rate citizens (the concept of citizenship is a selective one) or there is only a limited number of social rights based on citizenship in the contemporary societies?
} 
concept of the woman: that is a child carer at home with interrupted, part time, low paid work, at best. Hence it was primarily focused on women within the particular welfare state arrangements, not on the role of different welfare states in constructing systematic differences between women and men.

The first impulse for a change, concerning the two scholarships ignoring each other came from two sides. The first one was Esping-Andersen's 'The Three Worlds of Welfare Capitalism' (1990). The second was Scandinavian analysts of gender effects of the Scandinavian welfare state. They both contributed to the idea that welfare states differ in their social and distributional effects and, if so, that some of them could be even 'women-friendly'. The phrase was introduced by Helga Hernes $(1984,1987)$ in the meaning that a 'women-friendly' welfare state (or a particular government measure) helps women's equal social participation and thus leads towards a reconstruction of gender relations in the direction of equal distribution of social resources. Several reasons make Esping-Anderson's work an unavoidable reference point. First, he defined the welfare state concept in broader terms so as to include the political organisation of the economy (political economy). Second, he introduced the concept of the welfare state regime that refers to a particular configuration of family - state - market in the provision of wellbeing. Further, he proposed to assess the welfare states' effect based on theoretical, qualitative criteria (as opposed to on expenditure levels). His main dimension of welfare state comparison is the extent of de-commodification it brings about. Hence, if class division in capitalist societies rests on the commodity status of a worker (his position on the labour market), a welfare state is effective (neutralises the class division) to the extent to which it de-commodifies him (that is renders his living standard independent from the labour market). Finally, and perhaps most importantly from the gender perspective - he presented welfare state regimes as mechanisms of stratification themselves.

After Esping-Anderson, to the best of our knowledge, there was no analyst of gender relations in the context of the welfare state who would seriously defend the point that the welfare states are all alike in respect to their consequences for gender relations. ${ }^{6}$ It was particularly difficult to defend after first analyses of the Scandinavian welfare state had shown its differential effect on gender relations in comparison to the Anglo-Saxon experience. ${ }^{7}$ But Esping-Anderson's typology (and his criterion of classification) was by no means uncritically accepted. At least three critical points can be pointed out. The first doubts the usefulness of the regime concept, given the complexity of women's positions in relation to the welfare state (Lewis 1997). The second one comes from an opinion that Esping-Anderson's typology rests upon a gender irrelevant set of criteria. What came under attack was

\footnotetext{
${ }^{6}$ Except, perhaps Jane Lewis' assessment that "...no country has succeeded in valuing unpaid work and no country has the gendered division of unpaid work shifted substantially" (1997: 170)

${ }^{7}$ These analyses will be discussed later in this paper.
} 
the conceptualisation of welfare states' success within a framework of the state market relationship, the concept of de-commodification and stratification perceived in class terms. A different set of gender relevant criteria that intersect with EspingAnderson's, was called for (Lewis 1992; Sainsbury 1996; Hobson 1994). The third line of criticism found Esping-Anderson's typology satisfactory and inclusive enough, provided that his dimensions were 'gendered' and few new, 'gender sensitive', dimensions added (Orloff 1993; O'Connor 1993). In a prompt and constructive response to this criticism Esping-Andersen revisited his welfare regime typology armed with a new concept - de-familialisation ${ }^{8}$, constructed to capture what he thought was the gender relevant aspect of welfare regimes (Esping-Andersen 1999).

\section{A comparative view of gender and welfare states}

The most important work on gendering welfare states in comparative perspective synthesises the achievements of the gender-informed welfare state analysis in national contexts and comparative 'mainstream' analysis of welfare state regimes. All the concepts describing women's position in the welfare state (under the assumptions of the particular type of welfare state and the particular gender division) became, within a comparative context, dimensions of variation in the gender content of welfare states. We intend to present the main themes of this work by discussing the most representative individual attempts. Although it can be said that there is an agreement in the relevant literature that welfare state systems differ in their gender content, the problem is dealt with from variety of perspectives, problem formulations and empirical concerns. The main points could be summed up as follows: 1) Given the sexual division of labour (men earn - women care), what is the redistributive outcome of different welfare states for men and women? 2) Given the preferable goal of female emancipation, what type of welfare state policy promotes it best? 3) What is the effect of different welfare states on the sexual division of labour itself? These three interests are seldom made explicit and are often combined in a particular work. Furthermore, at this point in the development of a framework for the analysis of variability in the gender content of welfare states, some important questions are still open. Are there distinct welfare regimes in respect to gender relations? If so, do they coincide with the worlds of welfare capitalism? Are welfare states coherent in their gender relevant policies? How should researchers deal with the complexity of women's position in relation to welfare states? Authors differ in their views of and answers to these questions.

\footnotetext{
${ }^{8}$ This concept will be explained later in this paper.
} 
Соииолошки преглед, vol. XLII (2008), no. 1, стр. 3-26

\section{1: Modification in the male breadwinner family assumption}

\section{Jane Lewis}

In Jane Lewis' 1992 article, the emphasis was on the assumptions about family form and typical gender roles historically underpinning welfare states. It is a real transitional article with one foot still in a tradition of feminist's deeply doubting the institution of the welfare state and rejecting the gender-blind 'mainstream' accounts of it, but with the other stepping into the field of welfare regimes and the variability of their gender content. This, in my opinion, helps us understand the choice Lewis made in respect to the dimension of welfare state variability (the salience of the male-breadwinner family model). She also places the focus on gender assumptions instead of on gender effects of different welfare regimes (that will be evident in the subsequent work by other researchers of the welfare state from gender perspective).

The male breadwinner family model in its ideal-typical form would

"find married women excluded from the labour market, firmly subordinated to their husbands for the purposes of social security entitlements and tax, and expected to undertake the work of caring (for children and other dependants) at home without public support" (Lewis 1992:162).

Although the model, in this form, was historically applicable only to middle class women in the late-nineteenth century in a few industrial countries, it was, in Lewis' opinion, a shared ideal incorporated into the foundations of modern social provision in Western countries. As a result, "historically women have gained [social] entitlements by virtue of their dependent status within the family as wives and mothers" (Lewis 1992:159). If so, the pervasiveness of the male-breadwinner family model cuts across 'mainstream' typologies of welfare regimes.

Still, Lewis' article explores how the model has been modified (in different ways and different degrees) in different countries ${ }^{9}$, and in that sense it is distinct from the earlier feminist writings which viewed the breadwinner model as an inherent feature of the welfare state. She has demonstrated that a variation in assumptions about a family model and male/female roles helps to predict a variation in the level and nature of women's labour force participation, the level of social service provision in regard to child-care, and the nature of husbands' and wives' access to social security. A particularly relevant point Lewis makes is that "any further development of the concept of 'welfare regime' must incorporate the relationship between unpaid as well as paid work and welfare"10 (Lewis 1992:159).

\footnotetext{
${ }^{9}$ She has compared France, Sweden, Britain and Ireland.

${ }^{10}$ She is referring to Esping-Anderson's focus on welfare state vis-a-vis market.
} 


\section{2: 'Caring regimes'}

\section{Diane Sainsbury}

Diane Sainsbury $(1994,1996)$ advances research on gender and welfare state variation on at least three points. First, she clearly spells out the dimensions of variations assumed to be correlated (and thus hidden) within the male-breadwinner model approach. Her dimensions include: the basis of women's entitlement; the bases of claims to benefits; benefit unit and contribution and recipient of benefits; taxation policy; employment policy; who is caring and how caring work is valued. The breaking of the male-breadwinner model into its component dimensions of variation helps to analyse individual policies across several countries without assuming an internal coherence of policies regarding gender issues. In her 1996 book Sainsbury analyses four Western countries (US, UK, the Netherlands and Sweden) on several dimensions of variation without the ambition of picturing these states as the representatives of distinct welfare state regimes. Further, Sainsbury demonstrates that the 'caring regimes' of different welfare states do not coincide with the strength of the breadwinner model. Namely, only two bases of women's social entitlement are discernible from the breadwinner model point of view: women as dependent wives (and mothers within a family) and women as workers. What is emphasised is the treatment of women's unpaid caring work in respect to social entitlements or women's entitlements in their capacity of workers. In Sainsbury's view, this leads to a neglect of variations in paid care in different welfare states as well as to a neglect of other bases of women's entitlements such as motherhood, citizenship and need. Finally, Sainsbury shifts the focus of analysis from gender assumptions to the gender effects of different welfare states, and adds to an analysis of normative structure of a particular state provision (that is, the basis of entitlement) an analysis of actual outcomes.

\section{3: Analytical power of 'lone mothers'}

\section{Barbara Hobson}

In line with Sainsbury's criticism of the breadwinner ideology model, Hobson $(1990,1994)$ makes a point that sexual division of labour does not necessarily entail inequality in the distribution of social resources. Strong breadwinner welfare states such as Britain and the Netherlands, for example, (marked by the treatment of married women as dependent wives for the purposes of social entitlements), may differ in respect to equality of distribution of social resources and services between men and women, as well as between women assuming different social roles.

An original contribution of Hobson to a framework for gender-sensitive welfare regime analysis is her suggestion of using the category of 'solo mothers' (or 'lone mothers' or 'single earner households', although it is not exactly the same) as an analytical category for understanding the gendered dimension of welfare states. The argument is that the position of a lone mother in a particular welfare state 
synthesises all the gender relevant features of that state. In the case of lone mothers it becomes transparent that what has been already recognised in the case of productive work should also be recognised in the case of caring work, that is that both should be evaluated and remunerated independently from marital arrangement. If a lone mother earns her living, her wage should obviously include the cost of caring (otherwise, the children will be without any care); if instead, she stays at home and cares for children herself, she should obviously be provided with living costs (otherwise, both her and her children will starve). In addition, the kinds of state support lone mothers receive (assuming that all married mothers are potentially lone mothers) may be a reliable measure of the equality in families by offering the possibility of opting out of marriage (if it turns into an oppressive relationship).

\section{4: A capacity to maintain an autonomous household}

\section{Ann Shola Orloff}

Ann Shola Orloff offers a 'gendered' version of the 'power resource' comparative analysis of welfare state regimes (Orloff 1993). Her scheme comprises three ${ }^{11}$ dimensions, representative of the gender content of welfare states. The first dimension refers to the relative share of the state, market and the family contribution to the welfare provision. She argues that

"state provision that helps to shift the burden from the family to the state, or from women to men within the family, furthers women's gender interests" (Orloff 1993:312).

The main instruments of the shift in welfare responsibility from family to state are publicly provided (and financed) services in care and parenthood. The way care is provided (and domestic work shared) helps explain women's employment patterns, which are in their turn relevant for women's access to employment related welfare benefits.

The second dimension is related to the welfare state stratification effect in regard to gender inequality. "Women are disproportionally disadvantaged when benefits reflect work-related inequality" (Orloff 1993:314), because of women's inferior status in the workforce. But welfare states reinforce gender hierarchy in another way by privileging full-time paid workers over unpaid workers (care and domestic work) and part-time workers (who combine part-time paid work with domestic and caring labour). It has been done through directing men's and women's basis of entitlements into two different tiers of the system of welfare provision social insurance programs (serving predominantly male clientele) and social assistance programs (targeting predominately female clientele). ${ }^{12}$ These programs entail different political evaluation in terms of 'earned' - 'non-earned', 'deserved' -

\footnotetext{
${ }^{11}$ The third one is itself composed of three independent ones.

${ }^{12}$ Here Orloff has in mind US experience and Nancy Fraser's work from 1989.
} 
'undeserved', and consequently, grant different levels of benefits. In the context of the stratification effect of welfare states, Orloff makes an interesting and far-reaching point relevant for further work on the gender analysis of welfare states, that is, gender division in fact cutting across two tier state programs. This point may be generally relevant, although Orloff drows her conclusion for the US experience. Apparently, social insurance covers male breadwinner headed households, including dependant family members: wives and children. Social assistance is, on the other hand, available to the households maintained by unemployed (or not fulltime employed) single women, who must base benefit claims on their status as mothers - single mothers. Hence, a two tiered system of social provision divides women through its different treatment of wives (insured through their husbands) and single mothers and reinforces the difference between two-parents and single parent families. The difference between two-parent and single parent families is indicative of the 'capacity to maintain an autonomous household'. It is assumed that an equal treatment of different family forms helps women exit potentially oppressive relationships. ${ }^{13}$

The crucial dimension that distinguishes welfare state regimes in EspingAnderson's analysis - an extent of de-commodification ${ }^{14}$ achieved, is in Orloff's framework only an element of the more inclusive concept of self-determination. The concept includes 1) de-commodification - describing an individual's relationship to the labour market (and makes sense, within the gender context, for the 'commodified' women only - that is, women with employment record), and 2) a capacity to maintain an autonomous household - describing an individual's relation to marriage.

"The capacity to form and maintain an autonomous household relieves women of the compulsion to enter or stay in a marriage because of economic vulnerability..." (Orloff 1993:321).

The right to exit an oppressive marriage is an equivalent to the citizen's wage: the former alters the power relations within marriages, while the later alters the power relations in the labout market.

"The state is women-friendly to the extent that it enhances women's leverage within marriage (e.g. by reducing domestic violence or imposing domestic obligation on men) or increases the absolute and relative standards of living of women-maintained families." (Orloff 1993:321)

In Orloff's view an autonomous household can be maintained through 1) access to paid employment (and shifting domestic/caring responsibilities), and 2) secure incomes for the full-time domestic/care workers (a maternalist strategy). The two routes to autonomous household reflect two alternative women's strategies as well as the two forms of 'women friendly' welfare states. The latter strategy is acco-

13 The importance of the possibility of exit from an unsatisfactory marriage was also emphasised by Hobson (1994).

${ }^{14}$ De-commodification is a capacity to maintain a standard of living as a matter of right. 
mplished if there is a) parity between benefits for stay-at-home mothers and wage earners' benefits and b) a standard of living for single mothers comparable to their married counterparts. Orloff's analytical dimensions can be schematically summarised in the following way:

I The extent to which the state has taken over the provision of welfare services, especially from the family (family-market-state configuration in provision of welfare);

II The basis of claims and their relative treatment (stratification dimension);

III The extent of women's self-determination;

1) The extent of de-commodification

2) The capacity to maintain an autonomous household.

a) Women's access to paid work

b) Secure incomes for the full-time domestic/care workers benefits

- Parity between benefits for stay-at-home mothers and wage earners'

- The difference in standard of living connected to the family form (single mothers compared to married mothers).

\subsection{European 'gender regimes'}

\section{Alan Siaroff}

Alan Siaroff has actually applied a multi-dimensional space constructed by three gender relevant dimensions of welfare states on a sample of 23 OECD countries (Siaroff 1994). His dimensions are female work desirability, family welfare orientation $^{15}$, and which parent is the recipient of benefits. It is interesting to note that family welfare orientation is shown not to correlate either with female work desirability or with the mother as chief recipient of benefits. On the other hand it is shown that the correlation between female work desirability and family benefits going to the female is highly significant. It renders, in effect, the three-dimensional space into a two-dimensional one within which countries group in four clusters. On that basis Siaroff suggests that there are four gender relevant welfare state regimes:

1) So-called protestant social democratic welfare states - Denmark, Finland, Norway and Sweden - "are the only nations to provide (comparatively) a true 'work -welfare choice' for women, in that female work as an end in itself is relatively desirable. Moreover, family benefits are high, and are always paid to the mother" (Siaroff 1994:95).

2) So-called protestant liberal welfare states - Australia, Canada, New Zealand, UK and US - are characterised by low family welfare, high female work desirability and women as recipients of family benefits.

3) So-called Christian democratic welfare states - Austria, Belgium, France, West Germany, Luxembourg and the Netherlands - are characterised by strong

\footnotetext{
${ }^{15}$ Based on Wilensky's measure of family policies in three areas: 1) maternity and parental leave, 2) public day care programs, and 3) flexibility of retirement systems.
} 
incentives to stay at home instead of looking for employment. Family benefits are generous, although mainly paid to the breadwinner (men).

4) Finally, so-called late female mobilisation welfare states - Ireland, Greece, Italy, Spain, Portugal, Japan and Switzerland are characterised by both low female work desirability and negligible family support schemes.

In our opinion, Siaroff's regimes should be interpreted in terms of the favourite feminist theme: female dependence. ${ }^{16}$ If women can rely (depend) on the market (employment), state (welfare benefits and public services) and men (marriage and not directly paid caring work) for their well-being, the welfare regimes listed above open up different 'dependence' choices for women. In the social democratic type the choice is between market and state; the liberal regime offers the market - men choice; in the Christian democratic countries the state is an alternative to men (marriage); finally, late female mobilisation states seem to be the case of no alternative, e.g. pure female dependence on marriage and men. The regimes may also be interpreted to represent the two (independent) welfare state strategies in respect to gender relations (as suggested by Orloff): equal employment opportunities for men and women and secure income for full-time domestic/care workers. If it is difficult to argue in favour of any of the two strategies in terms of "women friendliness', both strategies could be shown to have a 'good' and a 'bad' variant. The social democratic regime represents a 'good' variant of a strategy of high female labour participation, since there is developed public services support, and the state provides a genuine alternative to work. Liberal regime, however is a 'bad' variant of the strategy based on the high female employment rate, because of employed mothers entirely depending on private provision of care (that the majority cannot afford) and a lack of the genuine alternative to employment, except in the form of social assistance benefits (that most often do not provide a living wage). Christian democratic regime, on the other hand, represents a 'good' variant of caring at home strategy, based on the family wage, providing a high living standard for lone mothers. The late female mobilisation regime, however, represents the 'bad' variant of the caring at home strategy, based on the breadwinner dependence in the marriage (without an economically feasible option of exit).

\section{6. 'From women in the welfare state to gender analysis of welfare state,}

\section{Mary Daly}

The most elaborate attempt to build an analytical framework for the comparison of gender content of welfare states comes from Mary Daly $\left(1994,1997^{17}\right)$. Her

\footnotetext{
${ }^{16}$ For an extensive review of all areas of interest of feminist approaches to the analysis of social policies see O'Connor (1996).

${ }^{17}$ This presentation is based on Daly's article from 1994 and her unpublished $\mathrm{PhD}$ thesis from 1997.
} 
analysis took two basic directions: 1) conceptualisation of the gender relevant aspects of welfare state provision; 2) modelling the gender relevant outcomes.

The gender relevant aspects of welfare state provision is conceptualised through distributive principles guiding the allocation of public resources. 'Public resources' include cash transfers, personal income taxation, and public services. The three elements that "capture the distributive principles of welfare as they may effect gender relations" (Daly 1997:57) are: a) the 'risk universe', b) the construction of entitlement, and c) the treatment of different family types. The 'risk universe' encompasses the range of risks covered, including the unique income risks for women as "defined by female biological construction (birth-giving) and the social construction of caring, as primarily a woman's role" (Daly 1997:59), the basis of claims (need, contribution, a citizen's right), and the hierarchical ranking of male and female risks and basis of claims. The construction of entitlement "speaks to the status of the applicant within the context of his/her family or household circumstances" (Daly 1997:60). It refers to the unit of entitlement and the treatment of 'dependants'. The treatment of different family types by various welfare states is relevant to look at specifically because of the single headed households (or lone mothers' families).

Further, what Daly suggests is that the welfare states effects in regard to service provision could be best conceptualised (and assessed) through the ' management of caring' defined to refer to " the tasks involved in caring for the personal needs of others, especially the young, the ill and the elderly" (Daly 1997:61). The concept directs attention, at a macro level, to the institutional division of labour between state, market and family with regard to caring work. At a micro level, in terms of individual lives, it "provides an entree to the construction of work as paid or unpaid and is therefore one key to uncovering the distribution of resources, roles and life opportunities between women and men" (Daly 1997:61).

Turning to the task of modelling gender relevant outcomes Daly looks at the two types of redistributive effects of welfare states. The first one - 'resource based' - refers to welfare states' effects on "the financial situation of women and men individually, but also in terms of how they structure resource distribution between them" (Daly 1997:63). The second one - 'incentives structures' - captures the more qualitative welfare states effect on gender relations. It refers to the capacity of either sex to participate, or not, in the labour market and/or family, that in turn determines the choices open to women and men. Finally, a connection between salient features of a social provision system and its gender relevant outcomes is found in the processes whereby 1) the maintenance of family members is constructed as a public or private responsibility and 2) the caring (predominantly female) labour is constructed as paid or unpaid. 


\section{Gender aspect of welfare regime change in East/Central Europe}

Observed against the background of the literature on gender and welfare states, the gender formation aspect of the processes involved in the radical transformation of productive and distributive institutions in East/Central European countries cannot pass unnoticed.

The ideology of social equality, which in the first place motivated the nationnalisation of private property, and centralised regulation of economic production and allocation of economic resources, has been giving ground to the objectives of economic efficiency. The concern for the welfare of citizens, which, under sociallism, impregnated the entire organisation of production and distribution, during the transformation has been moved to a separate institutional realm of social policy. A broad and universal system of welfare provision, under socialism, was based on guaranteed employment, centralised determination of both wages and prices, employment related social benefits of almost universal coverage and high replacement rates, and direct provision of goods and services, in the form of an additional income. Through a radical institutional separation of the realm of economy from the realm of social policy, this system has been replaced with a system of income protection designed as an institutional supplement to the labour market as a main source of living of citizens, compensating for social risks ex post. A "socialist welfare regime" has been transforming into a "social market economy". At the individual level of analysis such a change resulted in the larger part of individual and family wellbeing depending on their market competitiveness (determining their access to employment, earnings, privately produced goods and services, as well as to contributory social benefits). The smaller part is allocated on the basis of vertical and horizontal equity considerations. Without any doubt, the introduction of the market as a dominant mechanism of the distribution of economic resources should be expected to have for its outcome an increased inequality of access to economic resources and, consequentially, an increased inequality of economic wellbeing between individuals (families). In this paper we are particularly interested in framing the impact this may have on gender inequality in economic wellbeing.

A part of socialist ideology of social equality defined by the chief distributional dictum: from everybody according to his/her best ability - to everybody according to his/her work contribution ${ }^{18}$, was to insure the full labour force participation of women, regardless of their family and marital status ${ }^{19}$. Not only were equal access

\footnotetext{
${ }^{18}$ The final goal was actually formulated as: from everybody according to his/her best ability - to everybody according to his/her needs. But it was considered not yet reachable in the given stage of economic development.

${ }^{19}$ Cynics may say that this was not an ideological commitment but a necessity for communist leaders who were politically and economically dependent on the support and labour of women. Whatever the underlining idea was, it does not change the structural outcomes.
} 
to all levels of education and training, equal access to all venues of employment and equal pay for equal work, legally guaranteed, but the whole series of institutions have been designed to make this happen. In particular, "financial support and social institutions were reorganised to facilitate simultaneous career advancement and motherhood" (Rosenberg 1991:137). The integration of women into the professions and skilled trades, and into higher education was successfully accomplished. By the 1980s about 90 percent of women of working age were either in training or employed. "The structural details of emancipation were largely in place" (Rosenberg 1991:137).

The state bore most of the cost of having and bringing up children. Countries developed an exemplary program of maternity and child-care support. Pregnancy and the early parenthood of employed persons were treated as a part of social labour $^{20}$ (as opposed to an individual's risk). It was paid and counted towards the pension, and return to work was guaranteed. Employing a pregnant or potentially pregnant woman, with the right to a paid maternity or parental leave, did not raise the cost for a particular employer, because in the end the cost was shared throughout the whole population. So it did not influence a woman-child-carer's access to employment. One of the cornerstones of the income of families with children was family allowances involving high monthly allowances per child, with payments rising with the number of children. Eligibility to most 'benefits' was tied to employment but with no reference to income.

With the retreat of the state from employment, income and, to some extent, family policies, an asymmetrical situation has been created for a child carer (traditionally - a woman) and a non-child-carer. In the absence of publicly organised and subsidised child care, and with unfavourable treatment of early motherhood, both financially and career-wise, a woman - who was a child carer might become less competitive in the labour market than a non-child-carer. At the same time, since the cost of children and their care largely became a family's 'private business', a woman - child carer needs more resources than before, and more than a non-child-carer. With, presumably, less income and bigger expenses, she is likely to be poorer than a non-carer, all other things being equal. If so, a woman - child carer might end up depending, in the reformed system of social protection, on some form of income support that may be an inferior source of income to both wages and earnings related benefits in the pre-reform 'income support' system. If this is so, the transformation may, in the long run, promote a traditional sexual division of labour according to which family labour is a predominant sphere of responsibility for women and paid work and the bread winner function is predominantly performed by men, a division that was seriously undermined in the socialist period.

In this section we describe our own framework for the analysis of the implications of the socio-economic transformation in post-socialist countries on gender inequality in economic wellbeing. Although heavily indebted to the scholarship on

\footnotetext{
${ }^{20}$ In Durkheim's usage of the concept.
} 
gender and welfare state in respect to the main analytical dimensions and most important concepts, our approach departures from it in several ways.

The main departure concerns the definition of the institutional set-up, variation of which, or in our case - transformation of which - is studied as a macro level determinant of gender inequality. While most of the above analysis refers to institutional arrangements covered by the terms social policy and welfare state, our analysis refers to welfare or claim regimes, the terms which encompass "the broader package of welfare production and distribution" (Esping-Andersen 1999:34). In the overcrowded vocabulary of social sciences any new terminology may easily be a source of confusion. However, the task of comparing the impact on inequality of such different socio-economic organisations as a socialist centrally planed economy and a market based economy requires a concept which is more encompassing than social policy and welfare state. Conveniently, the concepts of welfare regime and claim structure have already been well defined by EspingAndersen $(1985,1999)$ and Rainwater (1986) respectively. For the former, welfare regime encompasses a political organisation of economy that establishes the rules for the distribution of economic resources between different groups of people, or, in other words, a configuration of the family, the market and the state in providing people's well-being. In Rainwater's terminology industrial and post-industrial welfare states embody

"a particular claims structure which organizes income distribution through the economy (labour market, capital market) and government agencies (transfers, services, jobs)" (Rainwater 1986:2). ${ }^{21}$

If so, one useful way of conceptualising the institutional transformation in postsocialist societies is, as Rainwater clearly spelled it out in a more general context,

"to think of [these] societies, as having different claim systems for the provision of the resources by which their members make their lives...The issue then becomes who makes what claims on what institutions and with what results." (Rainwater 1986:14)

Our aim in so doing is to use the language within which the work and the claims from work (earnings) could be placed under the same roof with the claims against the state (such as family allowance) or arising out of family relations (such as a claim to unpaid child-care). From this point of view, we avoid perceiving earnings from work as an outcome of the iron law of supply and demand, and beyond any political contention, as opposed to claims arising from the welfare system which are prone to government intervention. Within the language of claims structure,

"'earnings' may be seen as quite as institutionally determined [and as much prone to political contention and an outcome of power relations] as claims on

\footnotetext{
${ }^{21}$ However close in their content, there is a subtle difference between the concept of welfare regime and claim structure. A welfare regime incorporates both the institutions of production and distribution of welfare, whereas claim structure focuses on the interplay of different institutions with specifically distributional outcomes discernable at the personal level.
} 
consumption arising out of kinship relation or through the welfare system." (Rainwater, 1986, pp. 12).

Furthermore, the concepts of claim structure, and in its dynamic version, claim process, enables us to perceive caring work (for analytical purposes) as a part of socially necessary labour and not a disposition that renders a carer a risky category if not married or employed (as is the case if one adopts a concept of the welfare state as only an ameliorative institution).

The advantage of comparing societies by reference to differences in claims structure could be illustrated by an example from socialist societies. The majority of the population claimed earnings from work as a matter of right, since a right to employment was granted in most socialist constitutions. Moreover, people expected a level of earnings which would guaranty a certain living standard. From the perspective of purchasing power, they demanded prices which would enable them a certain level of consumption, given the wages they had earned. These sort of claims against the state must sound totally misplaced to a person used to economic processes being 'regulated' by market forces and outside the domain of state intervention. At the same time, a highly rational in capitalist societies, claim to resources based on property rights was completely illegitimate in socialist societies.

Our second departure from the usual comparative analysis of welfare regimes from the gender perspective concerns the focus of analysis on the differential impact of the institutional changes on different categories of women, instead of simply comparing women to men. A review of the literature on the gender content of different welfare states reveals that there is a broad consensus, at least in theory, that men and women have differential access to economic resources, not because of their natural differences but because of the sexual division of work and family labour (men work, women care), and their differential appraisal, all other things being equal. If on a higher level of abstraction we disregard the close affiliation between sex and gender role, the gender content of welfare state (or a particular social policy) points at the location and the treatment of caring work, resulting in a particular economic status of the carers (regardless of their biological sex). Sainsbury $(1994,1996)$ talks about "caring regimes"; Hobson $(1990,1994)$ points at different valuation of caring work by different welfare states; Orloff (1993) introduces a dimension for the gender analysis of welfare states which accounts for the extent to which the state takes over the caring work from the family (a dimension which Esping-Andersen (1999) calls de-familialization). Further, the main dimensions on which Siaroff (1994) compares 'gender regimes' include maternity and parental leave arrangements, public day care programs, and flexibility of retirement systems in relation to how caring work counts towards the pension. Daly (1997) suggests that the welfare states' effects in regard to service provision could be best conceptualised (and assessed) through the ' management of caring' for the personal needs of others. Finally, the creator of the phrase 'womenfriendly' welfare state, Hernes (1987) defined it as an active policy commitment to 
lessening the caring burdens of the family. Closely related to the treatment of caring work in welfare state is another recurring theme: the capacity of a carer to maintain an autonomous household (Orloff 1993), the possibility of opting out of marriage (Hobson 1990, 1994), the treatment of different family types (Orloff 1993; Daly 1997).

Hence, we believe that we capture the best spirit of gender analysis of welfare states if we study the economic outcomes of the socio-economic transformation as they relate to 'gender' by reference to the access to societal economic resources of a 'child carer' compared to a person with no children. We suggest that this access would also depend on the age of children and the child carer's marital status ${ }^{22}$. To study the economic outcomes of the regime transformation as they relate to gender by comparing women to men, falls short of an answer, in our opinion. This is a much more common approach, but also the approach in which the crucial characteristic determining the access to economic resources may be lost (since there are non-child-carers among women as well as child-carers among men). A good test of the adequacy of framing gender inequality in terms of differential access to economic resources between women child-carers and non-child-carers, instead of differences between women and men, is to ask yourself whether gender inequality increases or decreases in an empirical situation when the wage differential between men and women decreases because the earnings of women without children increase relative to men's earnings, but at the same time the earnings of women child carers decrease relative to both men's earnings and the earnings of women without children. In our opinion gender inequality (interpreted as inequality between child-carers and non-child-carers) increases in such situation, but if measured simply on the differences between men and women, the result would be that gender inequality decreases. ${ }^{23}$

We recognise that there is more to female gender than just caring work, however important it may be. In particular, the labour market participation of women with children (and married women with children specifically) is not exclusively regulated by the availability of child-care services. Gender roles are culturally and psychologically enforced and in most societies they translate into low labour market participation rates, lower level of qualifications and occupational segregation of women, which in turn lead to wage differences between men and

\footnotetext{
${ }^{22}$ We are actually not interested in the status, but in whether a child carer lives alone or in a couple. For the reason of simplicity, we will refer to living alone as to 'single' and to living in a couple as to 'married'.

${ }^{23}$ If we strictly followed this line of analysis we would study the gendered economic outcomes of the socio-economic transformation by comparing groups of people, regardless of their sex, with different marital (married/single) and familial (children/no children, small children/grown up children) situations. However, empirically speaking, women are the ones who predominantly take over the role of caring, and also, this role affects their economic situation more profoundly than it does for men, who, we believe, deal with the child caring role differently.
} 
women. However, in exploring the impact of institutional change on expected increased inequality between child-carers and non-child-carers living in different marital arrangements, our aim is to avoid having to account for any determinants other than the institutional change. Moreover, in most post-socialist societies at least some of the above determinants do not apply since labour market participation rates and levels of qualification were roughly equal for both men and women at the beginning of the transformation.

Thus, we suggest studying the impact of the welfare regime change in postsocialist countries on income inequality between child-carers and non-child-carers by comparing the incomes of different categories of women instead of income of women and men. ${ }^{24}$ Although this analysis is deeply rooted in the tradition of gender inequality, we appreciate that most readers may find it inappropriate to dissociate gender from sex in empirical analysis, so in the rest of the paper we will use the phrase inequality between women with different family and marital status, instead of gender inequality.

We distinguish six categories of women classified based on three dimensions of variation: 1) whether they have children or not; 2) whether their children are younger or older; and 3 ) whether women are married or single:

- Married women without children

- Single women without children

- Married women with older children (older than 9)

- Single women with older children

- Married women with younger children (9 and younger)

- Single women with younger children

A recognition of the 'family gap' as an important aspect of gender inequality comes form another stream of scholarship, addressing women's incomes and income inequality by studying income distribution across family types (Webb 1993; Joshi, Paci and Waldfogel 1999). It is considered

"an important and under-researched issue for the economics of the family as well as for the economics of gender. At a time of mothers' increasing labour market participation, a wage gap between mothers and other women could potentially represent a considerable part of the cost of childbearing (Joshi 1990). Moreover, if responsibility for children reduces a woman's earning power, directly or indirectly, motherhood becomes a specific source of women's labour market disadvantage across the board relative to men. Thus, the "family gap" could be an important component of the gender gap in pay (Waldfogel 1998A)." (Joshi, Paci and Waldfogel 1999:543).

This brings us to the third departure of our own analytical framework from the scholarship on gender and welfare state presented in the second section of this paper. Notwithstanding the importance of the assumptions, normative systems and

${ }^{24}$ The assessment of such an impact is actually conducted in the authors DPhil thesis, on the case of Hungary. 
ideologies about a proper family form, as well as the ascribed gender roles underpinning the particular institutional arrangements, our analytical framework is primarily concerned with the outcomes of different welfare regimes. More concretely, we focus on the impact of the institutional transformation in post-socialist countries (welfare regime change), on the economic well-being of women with different family and marital status. This impact is in turn measured as an effect of the transformation on the inequality of cash income assembled from various sources into distinctive income packages by different categories of women. With Rainwater (1986:192) we view "the packaging of [women's income] using different kind of claims as a central fact of [their] economic status".

Instead of including only sources from which women receive income in their own right, we suggest to measure their economic wellbeing by the income they have available due to their membership in a household. ${ }^{25}$ An unemployed married woman and an unemployed single woman may have identical independent incomes - i.e. little or no income at all; however they differ in their economic wellbeing since the married woman may get a share of her husband's income. Thus, we measure the economic wellbeing of women living in different household types by their 'share' of total household disposable money income - which is made up of all personal and household cash income sources pooled together, minus taxes and plus social transfers, assuming the equivalent sharing of total household income within a household ${ }^{26}$.

Income packages could be composed of income derived from such sources as husband's wage, wife's wage, income from assets, money value of household agricultural production for household consumption, income from social transfers such as unemployment benefits, family allowance, child care allowance etc. As transformation progresses and the claim structure change ${ }^{27}$ through pulling the state out of employment and wage policy as well as from the provision of public services, and through the change in entitlements, replacement rates and coverage of social benefits $^{28}$, the income packages of different categories of women change too, in terms of their structure and the level of income from various sources. As a result, the inequality in income between women of different family and marital status will change too. In a nutshell, the crux of our argument is that welfare regime change

\footnotetext{
25 "In many cases an individual's access to independent income will be a poor indicator of living standards" (Webb 1993).

${ }^{26}$ The income variable on which all the subsequent analysis is performed is described in detail in Chapter Three of the author's unpublished DPhil thesis.

${ }^{27}$ The kind of claims we are particularly interested in relate to labour force participation of women with children, but also to their entitlements to social transfers.

${ }^{28}$ The process of institutional transformation in East/Central European countries in general and in Hungary in particular is described in detail in Chapter Two of the author's unpublished DPhil thesis.
} 
differentially impacts the economic status of women belonging to different family/household forms, and that this will be observable as increased income inequality between them. Nevertheless, looking at the gender outcomes of the welfare regime change on the bases of the change in inequality of income assembled from various sources among women with different family and marital status confers more than change in money inequality. It confers the changing position and status on the basis of which these women can reasonably assert their claims to income derived from the state and economy. (Rainwater 1986:19).

The two main ideas guide our analysis of welfare regime/claim structure change:

1.The first refers to the variable extent of de-familialization in compared welfare regimes. The concept refers to the "policies that lessen individuals' reliance on the family; that maximize individual's command of economic resources independently of familial or conjugal reciprocities" (Esping-Andersen 1999:45), or in Orloff's terminology, the concept means the (variable) capacity of women (women with children, in particular) to maintain an autonomous household (Orloff 1993).

2. The second idea refers to the variable extent of de-comodification of women with children in the compared welfare regimes. It refers to the policies which reduce (or enhance) individual's reliance on the labour market.

More concretely, on the level of measurable indicators, the two concepts are reflected in the variable:

1. access to paid work (and to relatively well paid work) by women with children (younger children in particular) - observed on the labour force participation rates and earning levels of wage recipients by different categories of women, in turn determined by general employment and wage policies and child care provision.

2. extent to which the state provides women with children with an alternative income to that of the markets - observed on the share of income women with children derive from these sources, the coverage rates and the benefit levels for recipients, in turn determined by maternal/parental leave arrangements, child care and family allowance entitlement rules, duration, and the replacement rates.

3 . location in the system of social protection of the risks of a child carer observed on the share of income coming from insurance based benefits relative to the share of benefits financed from the general revenues, in turn determined by the prevalent basis of entitlement as well as maternity/parental leave arrangements ${ }^{29}$

Our main expectation is that as a new 'claim structure' has emerged, the income differential will increase between women without children (both married and single), on one side, and women with children (married and single, with older and with younger children), on the other. Furthermore, on another dimension of classification, the income differential will increase between women with younger

\footnotetext{
${ }^{29}$ Depending on the employment status of mother/parents, maternal/parental leave arrangements could be perceived either as an alternative income to market or as a risk management policy.
} 
children (both married and single) and all other women. The first dimension of classification of women is expected to capture the impact of the reallocation of financial responsibility for children and their care between different claim systems (state, market and family). The second dimension is supposed to provide an insight into the impact of welfare regime change on the access to and the quality of employment of women with young children. The radical transformation in postsocialist countries brought about the establishment of competitive labour markets. The labour market competitiveness of women with young children may be weakened by child-care obligations. This dimension should also capture the impact of the change in institutional arrangements related to the treatment of pregnancy and early parenthood. We also analyse the change in income differential between married and single women with young children. The change in income differentials along the dimension of marital status of women with young children indicates the impact of the institutional rearrangements on the choices women with young children make in respect to employment vs. full time child-care at home, depending on whether they live alone or in a couple.

To sum up: if frameworks for studying the gender content of welfare states developed so far provide a good orientation for what to look at in order to predict gender outcomes of institutional transformation in East/Central Europe, research conducted within the context of East/Central Europe today should help select analytically promising aspects of these frameworks, worth further developing. We suggest that these are (among others): 1) focus on gender effects as opposed to gender assumptions of a welfare state; 2) focus on gender relations as a (variable) feature of a society and not simply women's issue; 3 ) an inclusive and broad concept of the welfare state; 4) a perception of caring work as an equally necessary social function as productive work, and not a 'natural' disposition; 5) the analysis of the position of 'lone mothers' in a society (perceived not as a risky group but the group that synthesis all the relevant information about a welfare state in respect to gender), and 6) a preference for dimensions of variation over the regime concept (at least as the starting point of analysis).

\section{BIBLIOGRAPHY}

Bussemaker J. and van Kersbergen K. (1994) 'Gender and welfare states: some theoretical reflections', in: Sainsbury, D. (ed.), Gendering welfare states, London, Sage.

Daly M. (1994) 'Comparing welfare states: towards a gender friendly approach', in: Sainsbury D. (ed.) Gendering welfare states, SAGE Publications. Pp. 101-118.

Daly M. (1997) Unpublished PhD thesis.

Esping-Andersen G. (1985) Politics against markets. Princeton, NJ, Princeton University Press.

Esping-Andersen G. (1990) The three worlds of welfare capitalism. Cambridge, Polity.

Esping-Andersen G. (1999) Social foundations of postindustrial economy, Oxford, Oxford University Press.

Fraser N. (1989) 'Women, welfare and the policies of need interpretation', in: Unruly practices. Cambridge, Polity Press. pp. 144-60. 
Социолошки преглед, vol. XLII (2008), no. 1, стр. 3-26

Hernes H. (1984) 'Women and the welfare state: the transition from private to public dependence', in: Holter H. (ed.) Patriarchy in a welfare society. Oslo, Universitetsforlaget, pp. 26-45.

Hernes H. (1987) Welfare State and Woman Power. Oslo, Norwegian University Press.

Hobson B. (1990) 'No exit, no voice: women's economic dependency and the welfare state.' Acta sociologica 33, pp. 235-50.

Hobson B. (1994) 'Solo mothers, social policy regimes, and the logics of gender', in: Sainsbury D. (ed.) Gendering welfare states, SAGE Publications. Pp.170-88.

Gordon L. (ed.) (1990) Women, the state and welfare. Madison, WI, University of Wisconsin Press.

Joshi H. Paci P. and Waldfogel J. (1999) 'The wages of motherhood: better or worse?', Cambridge journal of economics, Vol. 23, pp. 543-564

Lewis J. (1992) 'Gender and the development of welfare regimes.' Journal of European social policy 3, pp. 159-73.

Lewis J. (1997) 'Gender and welfare regimes: further thoughts', Social politics, Summer, pp. $160-176$.

Marshal T.H. (1950) Citizenship and social class. Cambridge, Cambridge University Press.

O'Connor J. (1993) 'Gender, class and citizenship in the comparative analysis of welfare states: theoretical and methodological Issues.' British journal of sociology, Vol. 44. No 3. pp. $501-518$

O'Connor J.S. (1996) 'From women in the welfare state to gendering welfare state regimes', Current sociology Vol. 44, No 2.

Orloff A.S. (1993) 'Gender and the social right of citizenship: the comparative analysis of gender relations and welfare state'. American sociological review. 58, pp. 303-28.

Pateman C. (1989) 'The patriarchal welfare state', in The disorder of women Stanford CA, Stanford University Press.

Pierson C. (1991) Beyond the welfare state? The new political economy of welfare. Polity Press.

Rainwater L. Rain M. and Schwartz J. (1986) Income packaging in the welfare state, Clarendon Press, Oxford.

Rosenberg J. D. (1991) 'Shock therapy: GDR women in transition from a socialist welfare state to a social market economy', SIGNS, Autumn, pp. 129-151.

Sainsbury D. (1994) (ed.) Gendering welfare states, SAGE Publications.

Sainsbury D. (1996) Gender, equality, and welfares states, Cambridge, University Press

Siaroff A. (1994) 'Work, welfare and gender equality: a new typology', in: Sainsbury D. (ed.) Gendering welfare states, SAGE Publications. Pp. 82-101.

Skocpol T. and Ritter G. (1991) 'Gender and the origins of modern social policies in Britain and the United States'. Stidies in American political development 5, pp. 36-93.

Webb S. (1993) 'Women's incomes: past, present and prospects', Fiscal studies, Vol. 14, no. 4 , pp.14-36.

Williams F. (1989) Social policy: a critical introduction. Cambridge, Polity.

Wilson E. (1977) Women and the welfare state. London, England, Tavistock. 
Горана Ђорић

Su $m$ m ary

Филозофски факултет

Ниш

\section{АНАЛИЗА СОЦИЈАЛНЕ ДРЖАВЕ И РОДНИ ОДНОСИ}

У овом раду аутор анизира најрепрезентативније доприносе упоредном проучавању импликација социјалне државе по родне односе. У првом делу, у раду се представља развој родне анализе и анализе социјалне државе, који је довео до повезивања ове две аутономне сфере теоријског и истраживачког интересовања; у другом делу, рад представља унутрашњи развој упоредне анализе социјалне државе из перспективе импликација различитих социјалних држава по родне односе, који је био омогућен предходно анализираним повезивањем два независна поља интересовања. Наслањајући се на ове доприносе, аутор излаже сопствени теоријски оквир за проучавање утицаја социо-економске трансформације у пост-социјалистичким друштвима на родну неједнакост у економском статусу. Аутор сугерише да се теоријски дефинисан родни садржај социјалних држава може емпиријски мерити упорећивањем еконимског статуса шест категорија жена класификованих на основу три димензије класификације.

Кључне речи: типови социјалне државе, родна неједнакост, режими бриге о деци, економска неједнакост породичних форми, породична политика. 